\title{
Luomus' Genomic Resources Collection Available as Open Data Through FinBIF
}

\author{
Gunilla Ståhls-Mäkelä ${ }^{\ddagger}$, Anniina Kuusijärvi ${ }^{\ddagger}$, Ville-Matti Riihikoski ${ }^{\ddagger}$, Leif Schulman ${ }^{\ddagger}$, Aino Juslén ${ }^{\ddagger}$ \\ ‡ Finnish Museum of Natural History LUOMUS, Helsinki, Finland
}

Corresponding author: Gunilla Ståhls-Mäkelä (gunilla.stahls@helsinki.fi)

Received: 10 Jun 2019 | Published: 13 Jun 2019

Citation: Ståhls-Mäkelä G, Kuusijärvi A, Riihikoski V, Schulman L, Juslén A (2019) Luomus' Genomic Resources Collection Available as Open Data Through FinBIF. Biodiversity Information Science and Standards 3: e37024. https://doi.org/10.3897/biss.3.37024

\begin{abstract}
There is an increasing demand for high-quality genetic samples for biodiversity research as the techniques are rapidly developing and the costs are decreasing. The Finnish Museum of Natural History Luomus, an independent research institute within the University of Helsinki holding and developing the national natural history collections, has joined the Global Genome Biodiversity Network (GGBN; http://www.ggbn.org/ggbn portal/) and established a Genomic Resources Collection (GRC) in 2018.
\end{abstract}

In March 2019, the Luomus GRC comprised 2500 DNA extractions and 4000 vertebrate tissue samples amassed in approximately the last 10 years. The DNA extractions are mainly of lichens, polypores, beetles, flies, molluscs and crustaceans of worldwide origin, reflecting the focal organism groups of research groups in Luomus. The deep-frozen tissue samples are mostly of Finnish birds and mammals, as accessions of vertebrate specimens acquired to Luomus' collections are sampled. High-quality whole-genome DNA extracts will also be prepared. We expect the GRC to increase rapidly in numbers of samples within the coming years. Furthermore, the collection will also serve the many active research groups in the Faculty of Biological and Environmental Sciences of the University of Helsinki.

The GRC collection follows the best practices of the Global Genome Biodiversity Network (GGBN) concerning long-term storage and physical quality of samples, and international agreements (the Convention on Biological Diversity, the Nagoya Protocol, CITES) as 
regards the legitimacy of the samples. The GRC samples are always cross-linked with the taxonomically identified and georeferenced voucher specimen from which it is separated. Each GRC sample gets a Unique Resource Identifier HTTP-URI, which is a derivative of the unique specimen ID used in Luomus' Collection Management System (CMS) 'Kotka'. The sample tubes are cryolabelled with the QR code on the lid of the tube.

The voucher specimens are deposited in Luomus' collections or in another international public repository. The data on the GRC samples form part of the Open Data distributed through the Finnish Biodiversity Information Facility FinBIF species.fi (Data policy: https:// laji.fi/en/about/960), and will be made searchable at the web portal in 2019.

The specific database functions to meet the needs of Luomus' GRC are developed by Luomus' Biodiversity Informatics Unit and implemented in Kotka. We have already implemented part of the database tools to manage the compliance with the Nagoya protocol. The tool for registering material transactions (donations / loans) makes use of the Application Programming Interface (API) provided by the Access and Benefit Sharing Clearing House (ABS-CH) and includes links to the ABS-CH webpage (https:// absch.cbd.int/). The ABS-CH shows the contact person or organization details of the provider country, and the country-specific requirements for access to genetic resources, when present. The necessary information and documentation (letter of Prior Informed Consent, Mutually Agreed Terms, Material Transaction Agreement, and other permits) are linked from the material transactions to the relevant specimens.

\section{Keywords}

Genomic Resources Collection, DNA, tissue samples

\section{Presenting author}

Gunilla Ståhls-Mäkelä

\section{Presented at}

Biodiversity_Next 2019

\section{Acknowledgements}

FMNH Luomus Genomic Resources Collection is part of the Helsinki Institute of Life Science (HiLIFE) research infrastructure network, and has been partially developed by HiLIFE infrastructure funding. 